Vol.01/ No. 02

Pages: 113-122

https://www.irojournals.com/iroeea

DOI: https://doi.org/10.36548/jeea.2019.2.006

\title{
SURVEY ON ROBOT PROCESS AUTOMATION APPLICATION IN VARIOUS INDUSTRIES
}

\author{
Dr. G. Ranganathan, \\ Professor, Electronics and Communication Engineering, \\ Gnanamani College of Technology, \\ Namakkal, India. \\ Email: profranganathang@gmail.com
}

\begin{abstract}
The Robotic Process automation (RPA) plays a vital part in the digital transformation scheme in maximum number of the organizations as they provide numerous of benefits over the conventional automation solutions that are out dated. The RPA provides an increased accuracy and productivity in the industries ensuring the cost savings and the reduced resource utilization with the technical barriers that are non-invasive. The paper presents the survey on the application of robot process automation in various industrial processes and the over view of the benefits in using the RPA.
\end{abstract}

Keywords: Artificial Intelligence, Machine Learning, Robotic Automation Process, Industrial Developments and Benefits

\section{INTRODUCTION}

The RPA enables the organizations to automate the works replicating the performance of the human beings, through various applications and the systems. The robot does not incorporate any complicate infrastructure and just extends interaction with the existing information technology unlike the traditional automation system.

It imitates the monotonous process of the human being $s$ by employing the software robots that are designed to capture and record the applications in order to execute transactions, compute data, generate responses and interconnect among various digital systems.

The RPA engages both the software and the strategic approaches to robotize the computation and effectively design process respectively by applying the script, macros and the algorithms to the process. The RPA automates the

ISSN: 2582-3051 
Journal of Electrical Engineering and Automation (EEA) (2019)

Vol.01/ No. 02

Pages: 113-122

https://www.irojournals.com/iroeea

DOI: https://doi.org/10.36548/jeea.2019.2.006

workflow, back office process, infrastructure in an organization substituting the human beings engaged in the repetitive process such as the clerical tasks etc. They modify the company environment by employing the virtual worker instead of the human workers, and ensure 100\% error free productivity compared to the humans who can show only an average production of $60 \%$, the change in the regular process can be just be intimated by few line changes in the software code. The tabulation below in the table. 1 provides the comparison between the conventional automation and the robotic process automation.

\begin{tabular}{|c|l|l|}
\hline Parameter & \multicolumn{1}{|c|}{ Conventional Automation } & \multicolumn{1}{c|}{ Robot Automation } \\
\hline Goal & Minimizes the execution time & Minimizes the human power \\
\hline Task & $\begin{array}{l}\text { Automates the monotonous Test cases } \\
\text { alone }\end{array}$ & $\begin{array}{l}\text { Ensures automation in all areas of an } \\
\text { organization }\end{array}$ \\
\hline Number of users & Limited & Can be accessed by all \\
\hline Technical strategy & Aids only a limited amount of soft ware & $\begin{array}{l}\text { Aids a wide array of software } \\
\text { environment }\end{array}$ \\
\hline Participation & Behaves as a virtual assistant & Behaves as the virtual workforce \\
\hline AI integration & Executes only the code fed in & $\begin{array}{l}\text { RPA integrates AI to provide a human } \\
\text { like operation }\end{array}$ \\
\hline Coding & $\begin{array}{l}\text { Specialist with coding knowledge is } \\
\text { required }\end{array}$ & Coding knowledge not required \\
\hline Implementation & Automates the product & Automates products and services \\
\hline Application & $\begin{array}{l}\text { Employed in the equality analysis }, \text { UAT } \\
\text { environments }\end{array}$ & $\begin{array}{l}\text { Employed in production units, front } \\
\text { office, back office etc. }\end{array}$ \\
\hline
\end{tabular}

Table.1 Difference between the Conventional automation and the RPA [22]

ISSN: 2582-3051 
Journal of Electrical Engineering and Automation (EEA) (2019)

Vol.01/ No. 02

Pages: 113-122

https://www.irojournals.com/iroeea

DOI: https://doi.org/10.36548/jeea.2019.2.006

Basically the RPA aims in developing a virtual environment that imitates the human actions; it performs highvolume repeated tasks with high accuracy compared to the humans with an automated report generation, validation and auditing, debt management, production management, quality assurance, data migration, filling in the gaps, revenue forecasting etc. the figure.1 below provides the procedure involved in the implementation process of the RPA

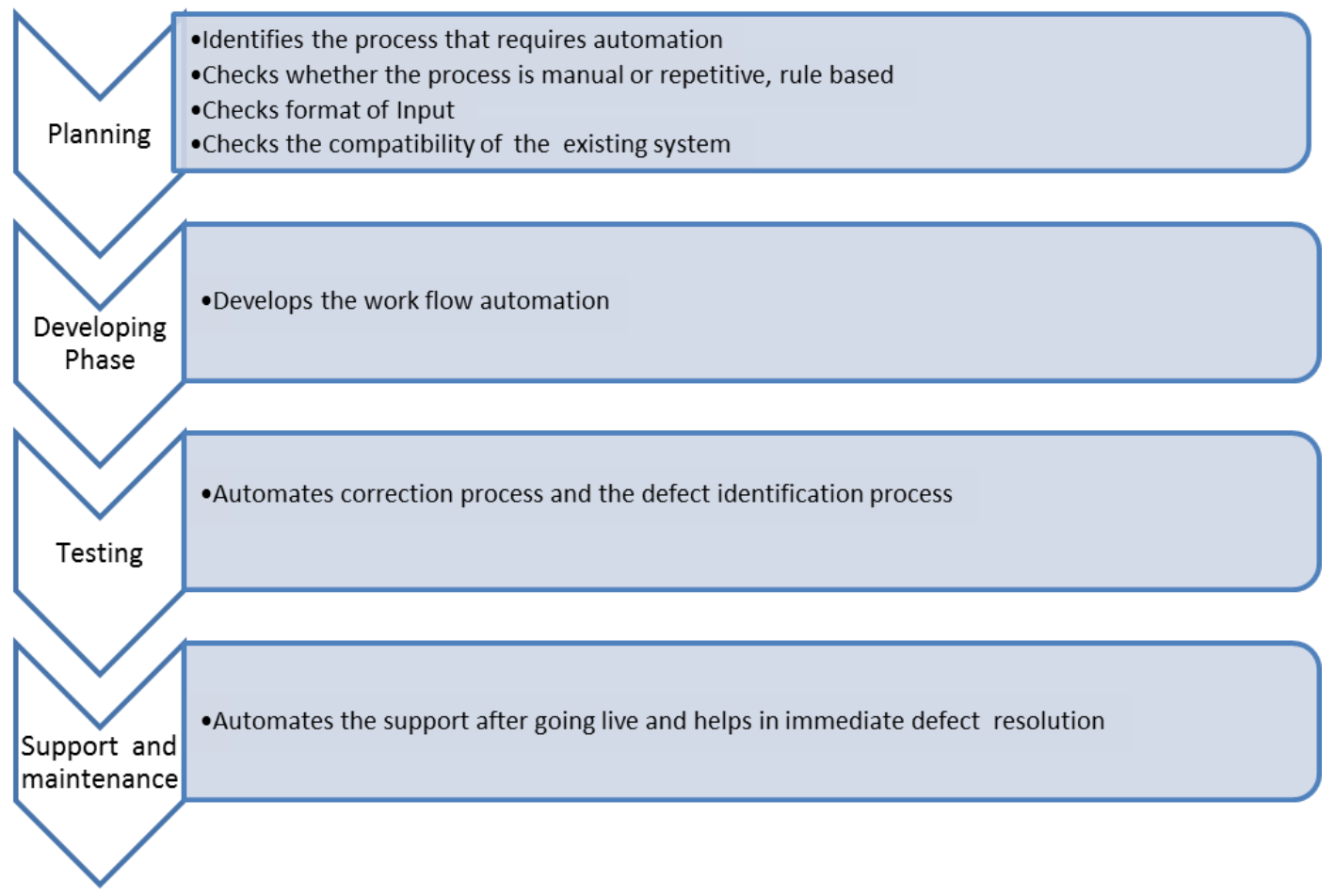

Fig.1 Implementation Process of RPA

The survey in the paper presents the application of the RPA in various industries and the benefits enjoyed by substituting robots instead of the humans.

ISSN: 2582-3051 
Journal of Electrical Engineering and Automation (EEA) (2019)

Vol.01/ No. 02

Pages: 113-122

https://www.irojournals.com/iroeea

DOI: https://doi.org/10.36548/jeea.2019.2.006

The paper organized with the literature survey of the robotic process auto automation in section 2 , the overview of the benefits of the RPA in section .3 followed by conclusion in the section .4

\section{LITERATURE SURVEY}

The section presents the literature survey about the association and the integration of the RPA in the various existing industrial process. The table. 2 below presents the survey of the industrial applications automation by employing the Robotics. 
Journal of Electrical Engineering and Automation (EEA) (2019)

Vol.01/ No. 02

Pages: 113-122

https://www.irojournals.com/iroeea

DOI: https://doi.org/10.36548/jeea.2019.2.006

\begin{tabular}{|c|c|c|c|}
\hline $\begin{array}{l}\text { Robotics in } \\
\text { industries }\end{array}$ & $\begin{array}{c}\text { Authors } \\
\text { description }\end{array}$ & Uses & Advantages \\
\hline $\begin{array}{l}\text { Automobile } \\
\text { industry }\end{array}$ & $\begin{array}{l}\text { Smys, S., and G. } \\
\text { Ranganathan [1] }\end{array}$ & $\begin{array}{l}\text { Sensing, control, picking, } \\
\text { dropping }\end{array}$ & $\begin{array}{l}\text { Reduces human power, enhances } \\
\text { accuracy, speed }\end{array}$ \\
\hline Drilling industry & Boyadjieff [2] & $\begin{array}{l}\text { Performs drilling, analysis } \\
\text { obstacle and limitations }\end{array}$ & $\begin{array}{l}\text { Reduces human physical stress, } \\
\text { reproduce best crew on rig }\end{array}$ \\
\hline $\begin{array}{l}\text { Protection } \\
\text { resource }\end{array}$ & Vijayakumar, T [5] & Flexible robotic electronic skin & $\begin{array}{l}\text { Protects the skin from unwanted } \\
\text { radiations in the industries }\end{array}$ \\
\hline Medical industry & $\begin{array}{c}\text { Manoharan [9], } \\
\text { Bhatnagar, Nitu. } \\
{[14]}\end{array}$ & $\begin{array}{c}\text { Surgical robots, } \\
\text { RPA in drug discovery, } \\
\text { Drug formulation process, etc. }\end{array}$ & $\begin{array}{l}\text { Eradicates human errors, allows self } \\
\text { correction and automation, handles } \\
\text { tremendous amount of data. }\end{array}$ \\
\hline Logistics & $\begin{array}{c}\text { Karabegović, I., E } \\
{[10]}\end{array}$ & Service Robots & Reduced processing time \\
\hline $\begin{array}{l}\text { RPA + Machine } \\
\quad \text { Vision }\end{array}$ & Luis Pérez [11] & Autonomous robots & Ensures accuracy, safety, processing time \\
\hline Construction & Chu [12], Tay [13] & $\begin{array}{c}\text { Robots in building } \\
\text { construction, road } \\
\text { construction and maintenance }\end{array}$ & $\begin{array}{l}\text { Over comes inefficiencyin the labor } \\
\text { intensive works }\end{array}$ \\
\hline Telecom Industry & Schmitz [15] & RPA as enabler & $\begin{array}{l}\text { Automatic transaction, careful } \\
\text { management, reduce } d \text { cost }\end{array}$ \\
\hline $\begin{array}{l}\text { Business } \\
\text { Organization }\end{array}$ & $\begin{array}{l}\text { Ansari, [17] } \\
\text { Madakam, } \\
\text { Somayya [16] }\end{array}$ & Moving physical robots & Accuracy in performing tasks \\
\hline RPA in purchasing & Muurinen, $[18]$ & Soft ware Robotics & Cost effective, performs high value task \\
\hline
\end{tabular}

Table.2 RPA in Industries

ISSN: 2582-3051 
Journal of Electrical Engineering and Automation (EEA) (2019)

Vol.01/ No. 02

Pages: 113-122

https://www.irojournals.com/iroeea

DOI: https://doi.org/10.36548/jeea.2019.2.006

\section{OVER VIEW OF BENEFITS OF RPA}

There are several benefits in employing RPA in the industrial process. The figure. 3 provides the overall benefits in employing The RPA in the business and the industrial process.
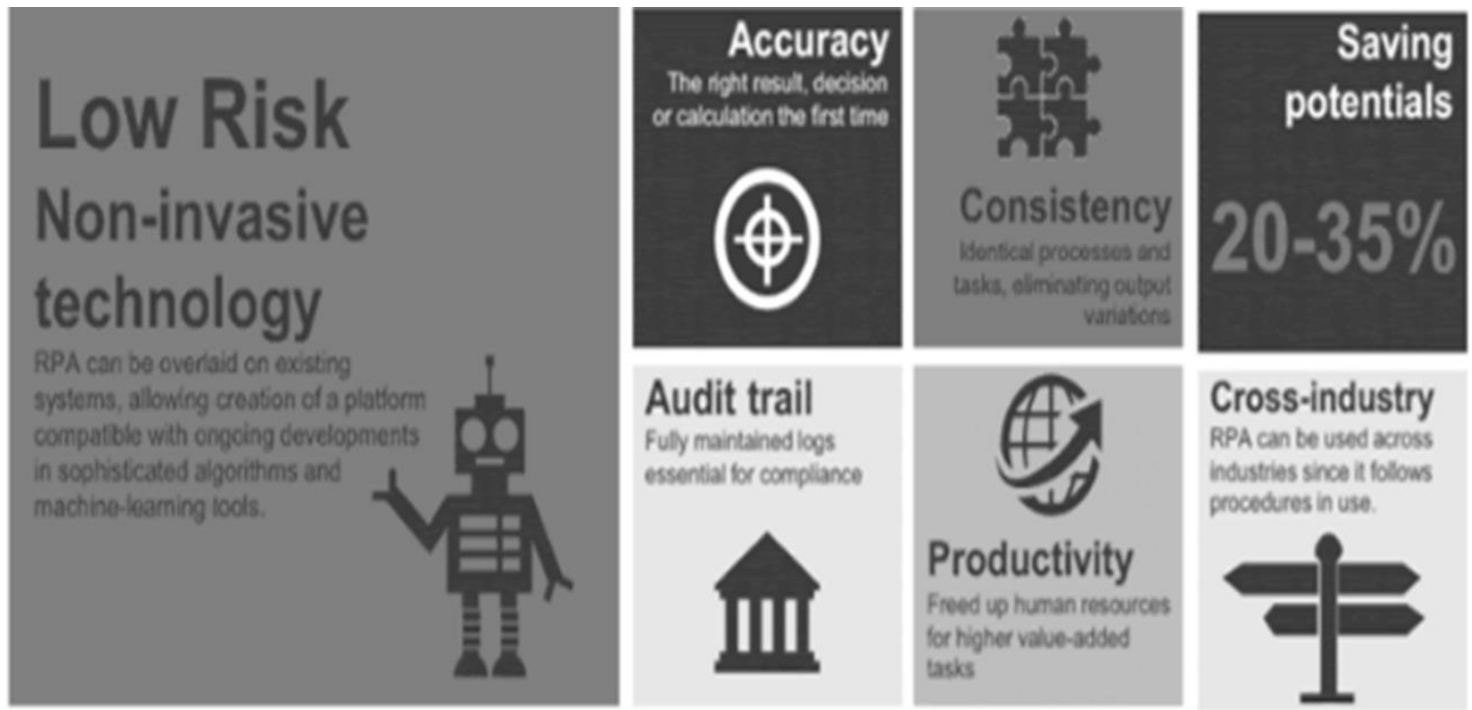

\section{Cross-industry}

RPA can be used across industries since it folloms procedures in use.
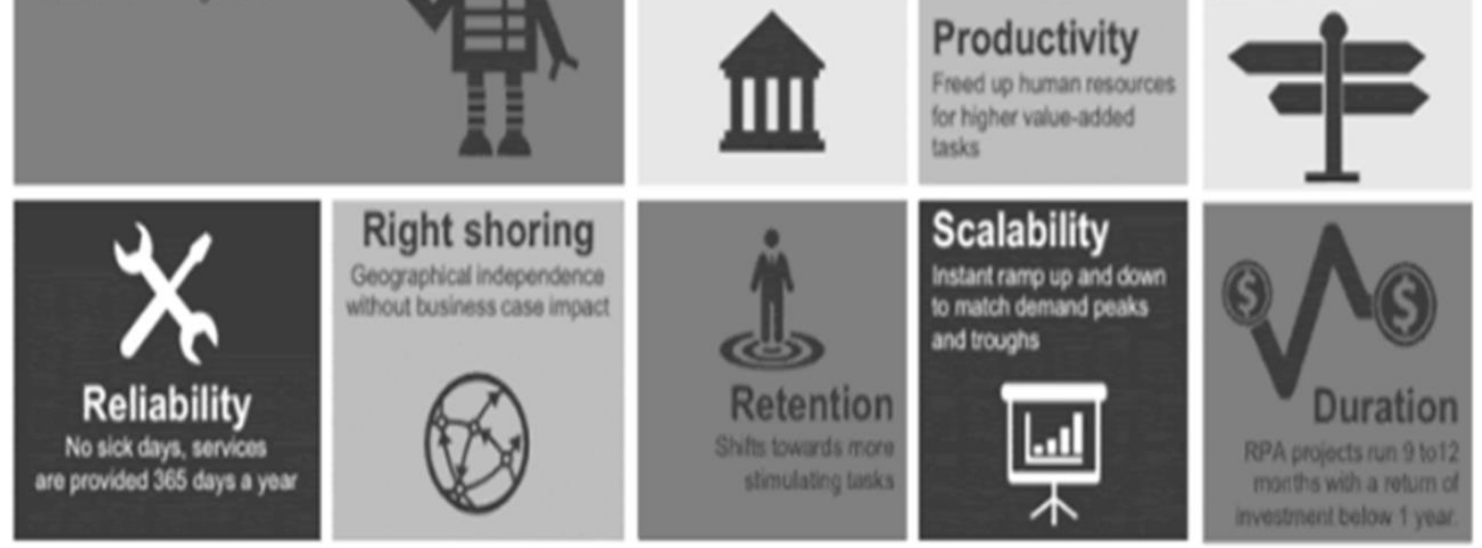

Fig.2 The RPA overall Benefits [21]

The RPA in the industrial process reduces the pain and the cost involved in performing the repetitive jobs, enhances the customer and employee satisfaction, by employing the machine learning applications, chat bots, and the 
Journal of Electrical Engineering and Automation (EEA) (2019)

Vol.01/ No. 02

Pages: 113-122

https://www.irojournals.com/iroeea

DOI: https://doi.org/10.36548/jeea.2019.2.006

providing the agent assisted self-services, and provides a assistance to agents enhancing their productivity and allowing more time for them to focus on customer experience. Increases the quality and the efficiency of the work done, minimizes the error in turn increasing the accuracy. The table .3 below provides the benefits and the disadvantages of the RPA in the industrial and the business process.

\begin{tabular}{|l|l|}
\hline \multicolumn{1}{|c|}{ Advantages } & \multicolumn{1}{c|}{ Disadvantages } \\
\hline Automates large number of process & $\begin{array}{l}\text { They are limited to the speed of the } \\
\text { application }\end{array}$ \\
\hline Cost are reduced significantly & $\begin{array}{l}\text { Needs reconfiguration even for } \\
\text { simple changes }\end{array}$ \\
\hline Saves time and resources & $\begin{array}{l}\text { Reconfiguration would lead to time } \\
\text { consumption }\end{array}$ \\
\hline $\begin{array}{l}\text { Programming skills are not needed to } \\
\text { configure a software robot. }\end{array}$ & Requires human supervision \\
\hline $\begin{array}{l}\text { Robotic process automation support and } \\
\text { allows all regular compliance process, }\end{array}$ & \\
\hline $\begin{array}{l}\text { Rapid model and deployment of } \\
\text { automation process, Effective, seamless } \\
\text { Build \& Release Management }\end{array}$ & \\
\hline It increases Scalability & \\
\hline
\end{tabular}

Table. 3 RPA Benefits and Disadvantages 
Journal of Electrical Engineering and Automation (EEA) (2019)

Vol.01/ No. 02

Pages: 113-122

https://www.irojournals.com/iroeea

DOI: https://doi.org/10.36548/jeea.2019.2.006

\section{CONCLUSION}

The robotic process automation enables the industries to automate the works replicating the human actions but with better performance. The survey presents the literature survey including the uses of the RPA in the various industries and provides the benefits of the RPA in the proceeding section, from the survey it is understood that the RPA strives to reduce the human stress and improve the accuracy in the tasks.

\section{References}

[1] Smys, S., and G. Ranganathan. "ROBOT ASSISTED SENSING, CONTROL AND MANUFACTURE IN AUTOMOBILE INDUSTRY." Journal of ISMAC 1, no. 03 (2019): 180-187.

[2] Boyadjieff, G. I. "The Application of Robotics to the Drilling Process." In SPE/IADC Drilling Conference. Society of Petroleum Engineers, 1988.

[3] Raj, Jennifer S. "A COMPREHENSIVE SURVEY ON THE COMPUTATIONAL INTELLIGENCE TECHNIQUES AND ITS APPLICATIONS." Journal of ISMAC 1, no. 03 (2019): 147-159.

[4] Raj, Jennifer S., and J. Vijitha Ananthi. "RECURRENT NEURAL NETWORKS AND NONLINEAR PREDICTION IN SUPPORT VECTOR MACHINES." Journal of Soft Computing Paradigm (JSCP) 1, no. 01 (2019): 33-40.

[5] Vijayakumar, T. "FLEXIBLE ROBOTIC ELECTRONIC SKIN WITH HIGH SENSITIVITY SENSOR ARRAYS." Journal of Electronics 1, no. 01 (2019): 43-51.

[6] Smys, S., and Jennifer S. Raj. "VIRTUAL REALITY SIMULATION AS THERAPY FOR POSTTRAUMATIC STRESS DISORDER (PTSD)." Journal of Electronics 1, no. 01 (2019): 24-34.

[7] Bashar, Abul. "SURVEY ON EVOLVING DEEP LEARNING NEURAL NETWORK ARCHITECTURES." Journal of Artificial Intelligence 1, no. 02 (2019): 73-82.

[8] Pandian, A. Pasumpon. "ARTIFICIAL INTELLIGENCE APPLICATION IN SMART WAREHOUSING ENVIRONMENT FOR AUTOMATED LOGISTICS." Journal of Artificial Intelligence 1, no. 02 (2019): 63-72. 
Journal of Electrical Engineering and Automation (EEA) (2019)

Vol.01/ No. 02

Pages: 113-122

https://www.irojournals.com/iroeea

DOI: https://doi.org/10.36548/jeea.2019.2.006

[9] Manoharan, Samuel, and Narain Ponraj. "PRECISION IMPROVEMENT AND DELAY REDUCTION IN SURGICAL TELEROBOTICS." Journal of Artificial Intelligence 1, no. 01 (2019): 28-36.

[10] Karabegović, I., E. Karabegović, M. Mahmić, and E. Husak. "The application of service robots for logistics in manufacturing processes." Advances in Production Engineering \& Management 10, no. 4 (2015).

[11] Pérez, Luis, Ínigo Rodríguez, Nuria Rodríguez, Rubén Usamentiaga, and Daniel García. "Robot guidance using machine vision techniques in industrial environments: A comparative review." Sensors 16, no. 3 (2016): 335.

[12] Chu, Baeksuk, Dongnam Kim, and Daehie Hong. "Robotic automation technologies in construction: A review." International Journal of Precision Engineering and Manufacturing 9, no. 3 (2008): 85-91.

[13] Tay, Yi Wei Daniel, Biranchi Panda, Suvash Chandra Paul, Nisar Ahamed Noor Mohamed, Ming Jen Tan, and Kah Fai Leong. "3D printing trends in building and construction industry: a review." Virtual and Physical Prototyping 12, no. 3 (2017): 261-276.

[14] Bhatnagar, Nitu. "Role of Robotic Process Automation in Pharmaceutical Industries." In International Conference on Advanced Machine Learning Technologies and Applications, pp. 497-504. Springer, Cham, 2019.

[15] Schmitz, Manfred, Christian Dietze, and Christian Czarnecki. "Enabling digital transformation through robotic process automation at Deutsche Telekom." In Digitalization Cases, pp. 15-33. Springer, Cham, 2019.

[16] Madakam, Somayya, Rajesh M. Holmukhe, and Durgesh Kumar Jaiswal. "The Future Digital Work Force: Robotic Process Automation (RPA)." JISTEM-Journal of Information Systems and Technology Management 16 (2019).

[17] Ansari, Wasique Ali, Paritosh Diya, Sahishnu Patil, and Sunita Patil. "A Review on Robotic Process Automation-The Future of Business Organizations." Available at SSRN 3372171 (2019).

[18] Muurinen, Juho. "Robotic process automation as an automation tool for improving purchasing processes." (2019).

[19] Karabegović, Isak, Edina Karabegović, Mehmed Mahmić, and Ermin Husak. "Implementation of Industry 4.0 and Industrial Robots in the Manufacturing Processes." In International Conference "New Technologies, Development and Applications”, pp. 3-14. Springer, Cham, 2019.

ISSN: 2582-3051 
Journal of Electrical Engineering and Automation (EEA) (2019)

Vol.01/ No. 02

Pages: 113-122

https://www.irojournals.com/iroeea

DOI: https://doi.org/10.36548/jeea.2019.2.006

[20] Araya, Darmont, and Francis Mosheh. "Role of Industrial Robotics Automation Systems." (2019).

[21] https://www.i-scoop.eu/robotic-process-automation-rpa/

[22] https://www.itconvergenceinsights.com/integrating-applications-using-rpa-technology 